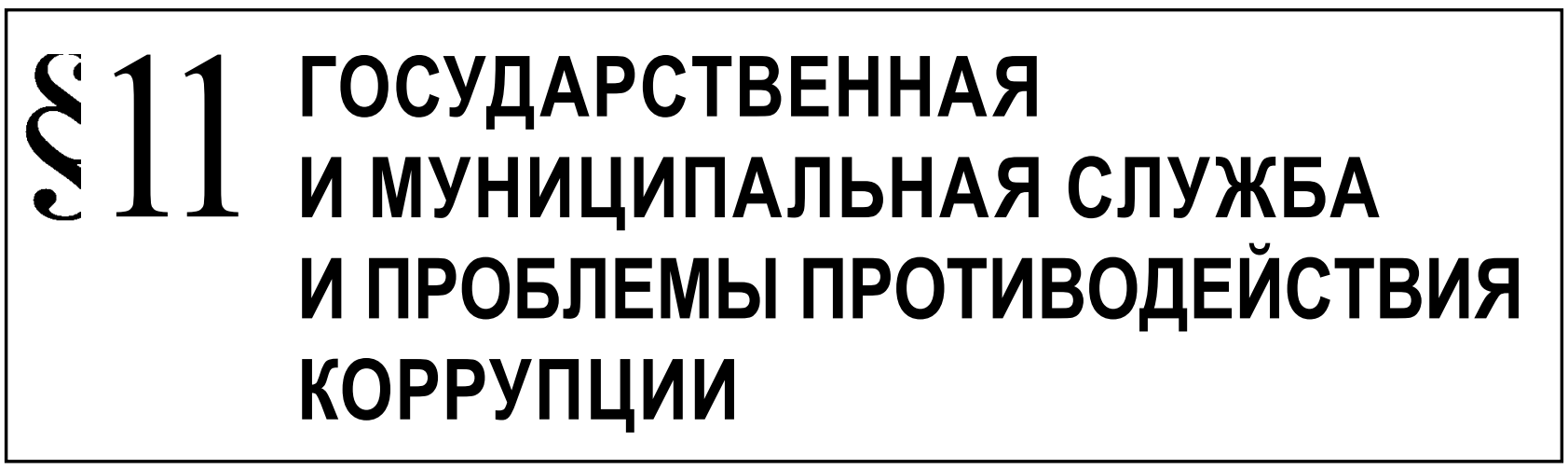

Кабанов П.А.

\title{
СИСТЕМА КОЛИЧЕСТВЕННЫХ ПОКАЗАТЕЛЕЙ РЕЗУЛЬТАТИВНОСТИ АНТИКОРРУПЦИОННОГО ПРОСВЕЩЕНИЯ КАК ИНСТРУМЕНТА ПРОТИВОДЕЙСТВИЯ КОРРУПЦИИ: ПРАВОВОЕ РЕГУЛИРОВАНИЕ И КЛАССИФИКАЦИЯ
}

\begin{abstract}
Аннотация. Объектом проведенного исследования является антикоррупционное просвещение. Предметом исследования выступают количественные показатели, характеризующие результативность антикоррупчионного просвещения как инструмента противодействия коррупции, отраженные в федеральных, региональных и муниципальных нормативных правовых актах. Цель исследование разработка системы показателей, характеризующих эффрективность (результативность) антикоррупционного просвещения. Основные задачи проведенного исследования: а) проанализировать и оценить основные показатели, характеризующие результативность антикоррупционного просвещения, закрепленные в действующих российских нормативных правовых актах; б) систематизировать существующие показатели, характеризующими результативность антикоррупционного просвещения; в) разработать и предложить собственные показатели, характеризующими результативность антикоррупционного просвещения и раскрыть их содержание. В качестве основных методов исследования использовались: сравнительно-правовой метод, методы структурного и системного анализа правовых документов и иные методы, используемые в современной российской юриспруденции. Научная новизна проведенного исследования заключается в том, что автором впервые в российской юридической науке проанализированы количественные показатели, характеризующие результативность антикоррупционного просвещения, отраженные в федеральных, региональных и муниципальных нормативных правовых актах.Практическая значимость проведенного исследования заключается в том, что предлагаемая автором система оценки качества организации и осуществления антикоррупционного просвещения может быть использована при мониторинге эффективности использование этого инструмента противодействия коррупции.

Ключевые слова: коррупция, противодействие коррупции, антикоррупционная политика, антикоррупционное просвещение, антикоррупционное консультирование, антикоррупционное законодательство, антикоррупционное информирование, показатели эффрективности, антикоррупционное поведение, антикоррупционная деятельность.

Review. The object of the research is anti-corruption education. The subject of the research is a range of quantitative indices characterizing the effectiveness of anti-corruption education as an instrument of corruption combating, contained in federal, regional and municipal normative legal acts. The aim of the study is to develop the system of indices characterizing the effectiveness of anti-corruption education. The main tasks of the research are: 1) to analyze and assess the main indices characterizing the effectiveness of anti-corruption education, contained in the existing Russian normative legal acts; 2) to systematize the existing indices characterizing the effectiveness of anti-corruption education; 3) to develop and suggest the author's indices characterizing the effectiveness of anti-corruption education and to reveal their essence. The author uses the comparative-legal method,
\end{abstract}


the structural and the systems methods of analysis of legal documents and other methods of the modern Russian jurisprudence. The scientific novelty of the research lies in the analysis of quantitative indices characterizing the effectiveness of anti-corruption education, contained in federal, regional and municipal normative legal acts. The described system of anti-corruption education effectiveness assessment can be used for the monitoring of efficiency of this instrument of corruption combating.

Keywords: anti-corruption behavior, effectiveness indices, anti-corruption informing, anti-corruption legislation, anti-corruption consulting, anti-corruption education, anti-corruption policy, corruption combating, Corruption, anti-corruption activity.

$\mathrm{B}$ опросы повышения качества противодействия коррупции в современном российском обществе находятся в центре внимания не только представителей органов публичной власти, но и специалистов различных отраслей знания. Им посвящено значительное количество нормативных правовых актов, научных, учебных, методических и публицистических работ различных по объему, содержанию и качеству, раскрывающих сущность механизмов и инструментов противодействия коррупции, в числе которых особое место придается антикоррупционному просвещению как средству противодействия коррупции. С учетом значимости данного инструмента противодействия коррупции в мае 2014 года Правительством Российской Федерации принята специальная Программа по антикоррупционному просвещению на 2014 - 2016 годы [43], а органами государственной власти субъектов Российской Федерации и органами местного самоуправления разработаны, утверждены и реализуются региональные и муниципальные программы (планы) по антикоррупционному просвещению [28; 34; 35; 40; 42]. В региональном антикоррупционном законодательстве антикоррупционное просвещение закреплено как средство противодействия [10;21; 22; $23 ; 24 ; 25 ; 26 ; 27] .0$ важности и значимости правового просвещения по вопросам противодействия коррупции в России говорилось высшими должностными лицами государства ещё в конце прошлого века [45]. Учитывая профилактическое значение антикоррупционного просвещения, в некоторых региональных нормативных правовых актах уже ставится вопрос о создании эффективной системы антикоррупционного просвещения [8; 31; 32].

Разумеется, что качественное решение задачи направленной на создание системы антикоррупционного просвещения даже на уровне субъекта Российской Федерации не возможно без тщательного научного анализа содержания и правового регулирования этого инструмента противодействия коррупции, а также федеральной, региональной и муниципальной практики его применения. Вместе с тем антикоррупционное просвещение как инструмент противодействия коррупции и его эффективность ещё не достаточно изучены. В арсенале российских исследователей имеются лишь небольшое количество научных публикации [1, c.105-111; 2, c.11-15; 3, с.47-53; 7, c.8-13; 47, с.322$323 ; 48$, с.188-191; 49, с.106-109; 50, с.5], в том числе и подготовленных автором настоящей работы [4, c.42-51; 5, с.27-29; 6, с.12-27], которые не только не раскрывают в полной мере содержание этого вида деятельности, но и оценивают его результативность. Более того, до настоящего времени российскими специалистами не подготовлено и не опубликовано ни одного крупного исследования, специально посвященного оценке качества антикоррупционного просвещения как инструмента противодействия коррупции. Поэтому попытки органов государственной власти разработать показатели оценки результативности использования антикоррупционного просвещения как средства противодействия коррупции в органах публичной власти не увенчались успехом [18; 19]. Все это свидетельствует не только о теоретической, но и практической значимости разработки показателей, характеризующих результативность антикоррупционного просвещения.

Целью нашего исследования является разработка системы показателей, оценки качества антикоррупционного просвещения. Для достижения названной цели требуется решение следующих задач: а) проанализировать и оценить основные показатели, характеризующие результативность антикоррупционного просвещения, закрепленные в действующих нормативных правовых актах; б) систематизировать имеющиеся показатели, характеризующими результативность антикоррупционного просвещения; в) разработать и предложить собственные показатели, характеризующими результативность антикоррупционного просвещения и раскрыть их содержание.

Эмпирическая база исследования включает в себя 252 федеральных, региональных и муниципальных нормативных правовых актов, регулирующие вопросы организации и осуществления антикоррупционного просвещения, в том числе документов антикоррупционного планирования, 108 региональных и муниципальных нормативных 
правовых актов, регулирующих организацию и проведение антикоррупционного мониторинга и предусматривающих отдельные показатели по оценке качества антикоррупционного просвещение.

В качестве основных методов исследования использовались: сравнительно-правовой метод, методы структурного и системного анализа правовых документов и иные методы, используемые в отечественной юриспруденции.

Проведенный нами анализ нормативных правовых актов, регулирующих вопросы организации и проведения антикоррупционного просвещения, антикоррупционного мониторинга и иных нормативных правовых актов показал, что этими нормативными правовыми актами устанавливаются только количественные показатели, связанные с использованием этого инструмента. Качественные показатели, характеризующие эффективность осуществления антикоррупционного просвещения, пока ещё не разработаны, а поэтому и не нашли своё отражение в нормативных правовых актах.

Как показал анализ нормативных правовых актов и иных документов основными количественными показателями, характеризующими исполнение мер антикоррупционного просвещения и отражающимися в различных материалах органов государственной власти и органов местного самоуправления (отчетах, справках, информационных письмах) являются следующие:

1) Количество проведенных публичных мероприятий органами государственной власти и/или органами местного самоуправления в формах:

а) заседаний коллегии органа государственной власти по вопросам противодействия коррупции;

б) конференций по антикоррупционной тематике;

в) круглых столов по антикоррупционной тематике;

г) научно-практических семинаров по антикоррупционной тематике.

2) Количество подготовленных, изданных, опубликованных или размещенных на официальных сайтах органов публичной власти в информационно-телекоммуникационной сети «Интернет» различного рода научно-практических изданий:

a) памяток по антикоррупционной тематике;

б) методических пособий по антикоррупционной тематике.

3) Количество проведенных индивидуальных консультаций с государственными (муници- пальными) служащими на тему антикоррупционного поведения.

4) Количество стендов в органах государственной власти и /или органах местного самоуправления, посвященных вопросам профилактики коррупции, а также частота их обновления [14; $15 ; 38 ; 39 ; 44]$.

Однако российская правовая действительность не ограничивается лишь основными количественными показателями, характеризующими исполнение мер антикоррупционного просвещения в ней можно встретить и дополнительные и уточняющие показатели. В отдельных региональных нормативных правовых актах встречаются и дополнительные показатели, характеризующие исполнение мер по антикоррупционному просвещению органами публичной власти. Так, в Республике Хакасия предусмотрено предоставление государственными органами информации о количестве размещенных в средствах массовой информации материалов направленных на антикоррупционное просвещение [17]. В Удмуртской Республике от органов публичной власти требуется учитывать количество размещенных в средствах массовой информации аналитической, разъяснительной и иной информации о деятельности органов власти по противодействию коррупции и установление единых требований к размещению и наполнению подразделов сайтов государственных органов по вопросам противодействия коррупции [16; 20]. В Пермском крае от представителей органов государственной власти дополнительно требуется отчитываться о количестве проведенных ими: а) публичных лекций по антикоррупционной тематике; б) организации и проведении совещаний по вопросам противодействия коррупции; в) создании антикоррупционных библиотек; г) проведенных семинаров для государственных и муниципальных служащих по антикоррупционной тематике [41]. Несколько иной показатель предусмотрен в деятельности органов государственной власти Ямало-Ненецкого автономного округа по антикоррупционному просвещению - количество проведенных совещаний с государственными (муниципальными) служащими по вопросам реализации антикоррупционного законодательства [12; 13; 30]. Правительством Ярославской области установлены дополнительные и уточняющие показатели оценки качества антикоррупционного просвещения. К ним, в дополнение к упомянутым ранее основным показателям, относятся:

1) количество проведенных круглых столов (семинаров) и количество участников этих ме- 
роприятий с разбивкой на категории: а) государственные служащие; б) муниципальные служащие; в) представители общественности, вовлеченные в антикоррупционную деятельность;

2) количество антикоррупционных материалов: а) разработанных; б) изданных (тираж); в) распространенных (экземпляров);

3) количество выпущенных в эфир программ по антикоррупционной тематике [33].

С учетом разрастающихся объемов организации и проведения «горячих линий» по антикоррупционному просвещению в органах публичной власти совершенно справедливо в Волгоградской области включен такой показатель как количество выданных разъяснений (консультаций) гражданам по вопросам противодействия коррупции [29]. В ежегодных отчетах о противодействии коррупции в Ростовской области количественными показателями выступают: а) количество специалистов, реализующих мероприятия по антикоррупционному просвещению; б) количество лиц, подвергшихся антикоррупционному просвещению [46].

Анализ нормативных правовых актов, регулирующих вопросы организации и осуществления антикоррупционного просвещения, свидетельствует о следующем. Во-первых, между органами публичной власти нет единства при оценке результативности антикоррупционного просвещения как инструмента противодействия коррупции, поскольку они используют различные количественные показатели для его оценки. Во-вторых, между органами публичной власти отсутствует взаимодействие и координация деятельности по организации и осуществлению антикоррупционного просвещения и оценке этого вида деятельности. В-третьих, требуется разработка и внедрение единых показателей антикоррупционного просвещения для органов публичной власти различного уровня и их классификация на однородные группы.

Исследование показателей организации и осуществления антикоррупционного просвещения в России позволяет выделить несколько групп таких показателей. Первая группа показателей отражает оценку правового регулирования антикоррупционного просвещения, свидетельствующая о формах правового регулирования его организации и проведении. Основными показателями, отражающими правовое регулирование антикоррупционного просвещения, выступают: 1) наличие отдельного нормативно-правового акта об организации и осуществлении антикоррупционного просве- щения; 2) наличие раздела об организации и осуществлении антикоррупционного просвещения в действующей программе (плане) по противодействию коррупции; 3) наличие нормативного правового акта о размещении информации по вопросам противодействия коррупции на официальном сайте органов публичной власти в информационно-телекоммуникационной сети «Интернет». Это группу показателей, с учетом региональной специфики, можно дополнить ещё одним - закрепление антикоррупционного просвещения как инструмента противодействия коррупции в региональном антикоррупционном законодательстве. Необходимость введения данного показателя обусловлена тем, что из 85 субъектов Российской Федерации лишь в 14 имеются положения, закрепляющие антикоррупционное просвещение как средство противодействия (профилактики) коррупции, а в большинстве из них этот инструмент законодательно не закреплен.

Названная система показателей оценки правового регулирования антикоррупционного просвещения может быть использована при осуществлении мониторинга правового регулирования антикоррупционного просвещения и проведении государственного (муниципального) либо общественного контроля за исполнением деятельности по организации и проведению антикоррупционного просвещения. (См.: Приложение - Раздел I.)

Вторая группа показателей включает в себя оценку качества правового регулирования антикоррупционного просвещения, свидетельствующая о достаточности форм и механизмов, ресурсов и технологий его осуществления в нормативных правовых актах. С помощью этой группы показателей можно осуществлять мониторинг качества правового регулирования антикоррупционного просвещения. При его разработке и осуществления требуется учитывать:

a) закрепленные федеральными нормативными актами формы осуществления антикоррупционного просвещения (антикоррупционное информирование и антикоррупционное консультирование);

б) перечень субъектов уполномоченных на осуществление антикоррупционного просвещения и объем их полномочий;

в) средства осуществления антикоррупционного просвещения, ресурсное обеспечение антикоррупционного просвещения;

г) показатели оценки качества осуществления антикоррупционного просвещения и возмож- 
ности с их помощью достичь поставленных целей и/или решить заявленные задачи;

д) формы и методы осуществления контроля за организацией и проведением антикоррупционного просвещения.

С использованием этой группы показателей необходимо будет получить ответы на следующие вопросы:

1) Предусмотрено ли нормативным правовым актом регулирование обоих форм антикоррупционного просвещения?

2) Имеется ли в нормативном правовом акте перечень субъектов, наделенных полномочиями по организации и осуществлению антикоррупционного просвещения?

3) Предусматриваются ли в нормативном правовом акте средства на осуществление антикоррупционного просвещения?

4) Имеются ли в нормативном правовом акте показатели оценки качества организации и осуществления антикоррупционного просвещения?

5) предусмотрены ли в нормативном правовом акте формы и методы осуществления государственного (муниципального) и/или общественного контроля за организацией и осуществлением антикоррупционного просвещения? (См.: Приложение - Раздел II).

Третья группа показателей предусматривает анализ и оценку качества организации осуществления антикоррупционного просвещения, отражающая наличие ресурсов и условий (возможностей, инструментов, средств, механизмов и технологий) исполнения различных форм антикоррупционного просвещения. С помощью названной группы показателей возможно осуществление мониторинга качества организации антикоррупционного просвещения в органах публичной власти. В качестве объективного показателя здесь может выступать наличие специализированного органа и/или лица, уполномоченного на организацию и осуществление антикоррупционного просвещения. Так, в Костромской области в качестве организатора антикоррупционного просвещения выступает Департамент региональной безопасности Костромской области [9], в Архангельской области эта функция возложена на региональное министерство образования и науки [36], в Новосибирской области полномочия по организации и координации антикоррупционного просвещения переданы региональному министерству юстиции [11], в Карачаево-Черкесской Республике анти- коррупционное просвещение являлась одной из основных задач упраздненного республиканского Управления по реализации антикоррупционной политики [37].

Не менее важным показателем может выступать и наличие средств, условий и возможностей антикоррупционного просвещения уполномоченным органом и/или лицом. Например, организатором антикоррупционного просвещения заявлено о проведении антикоррупционного интернет-консультирования населения с использованием современных информационных технологий, но сотрудник, уполномоченный на его осуществление, не имеет доступа к информационно-телекоммуникационной сети «Интернет» или не обладает достаточной квалификацией для его осуществления. В данном случае показателем может выступать наличие квалифицированных специалистов (прошедших повышение квалификации или профессиональную переподготовку) по вопросам противодействия коррупции и/или организации и осуществления антикоррупционного просвещения. Поэтому показателем организации осуществления антикоррупционного просвещения должно стать наличие такого института как система организации и осуществления антикоррупционного образования лиц, организующих, обеспечивающих и осуществляющих антикоррупционное просвещение.

Важнейшим показателем оценки качества организации антикоррупционного просвещения в органах публичной власти является организация ряда мероприятий: а) «горячих линий» по вопросам антикоррупционного просвещения; б) коллегий по вопросам антикоррупционного просвещения; в) совещаний по вопросам антикоррупционного просвещения.

Ещё одним показателем, отражающим качество организации антикоррупционного просвещения является наличие в органах публичной власти системы контроля за осуществлением антикоррупционного просвещения, отражающая его периодичность и качество.

В качестве самостоятельного показателя организации антикоррупционного просвещения может выступать наличие системы мониторинга осуществления антикоррупционного просвещения, отражающая его периодичность и результативность.

Важнейшую роль в осуществлении оценки качества организации антикоррупционного просвещения выступает наличие механизмов и инструментов 
общественного контроля за организацией и осуществлением антикоррупционного просвещения.

Не менее значимым показателем оценки качества организации антикоррупционного просвещения в органах публичной власти является наличие специальных информационных стендов по вопросам противодействия коррупции, раскрывающих содержание антикоррупционной деятельности этих органов, а также их количество и качество. (См.: Приложение - Раздел III).

Четвертая группа показателей должна предусматривать оценку качества исполнения в органах публичной власти антикоррупционного просвещения его субъектами, с помощью которых возможно осуществление мониторинга качества осуществления антикоррупционного просвещения. В этой группе количественных показателей относятся: а) количество проведенных коллегий, совещаний и иных рабочих мероприятий по вопросам антикоррупционного просвещения; б) количество проведенных конференций, круглых столов, научно-практических семинаров по вопросам противодействия коррупции с разбивкой по количеству лиц, участвовавших в них в зависимости от статуса (научно-педагогические кадры, государственные и муниципальные служащие, иные категории лиц); в) количество опубликованных в средствах массовой коммуникации информационных материалов по вопросам антикоррупционного просвещения; г) количество выпущенных в эфир программ по вопросам антикоррупционного просвещения; д) количество проведенных «прямых линий» по во- просам антикоррупционного просвещения; е) количество лиц, получивших антикоррупционное консультирование с разбивкой по категориям; ж) количество подготовленных, опубликованных и распространенных изданий (книг, памяток и пособий) по вопросам противодействия коррупции и их тираж; 3) количество лиц, осуществляющих антикоррупционное просвещение с разбивкой по категориям (государственные и/или муниципальные служащие, научно-педагогические кадры, представители институтов гражданского общества, вовлеченные в антикоррупционную деятельность и др.); и) количество лиц, прошедших повышение квалификации по вопросам организации и осуществления антикоррупционного просвещения; к) наличие стендов с материалами, направленными на антикоррупционное просвещение государственных (муниципальных) служащих и иных лиц; л) количество положительных отзывов в средствах массовой коммуникации по вопросам организации и осуществления антикоррупционного просвещения. (См.: Приложение - Раздел IV).

Разумеется, что предлагаемая нами система количественных показатели оценки качества организации и осуществления антикоррупционного просвещения в органах публичной власти является рабочей и отражает лишь базовые показатели первого этапа оценки. Безусловно, что вслед за первым этапом появятся и второй, предполагающий разработку в перспективе новых количественных и качественных показателей организации и осуществления антикоррупционного просвещения.

Приложение №1.

ПРИМЕРНЫЙ ПЕРЕЧЕНЬ показателей оценки качества антикоррупционного просвещения

\begin{tabular}{|c|c|c|c|}
\hline $\begin{array}{l}\text { № } \\
\text { П/ா }\end{array}$ & Показатель & $\begin{array}{c}\text { наличие / пол- } \\
\text { ное наименова- } \\
\text { ние и выход- } \\
\text { ные данные }\end{array}$ & $\begin{array}{l}\text { отсут- } \\
\text { ствие }\end{array}$ \\
\hline 1 & 2 & 3 & 4 \\
\hline \multicolumn{4}{|c|}{ Раздел І. Оценка правового регулирования антикоррупционного просвещения } \\
\hline 1.1. & $\begin{array}{l}\text { Наличие отдельного нормативного правового акта об организации и осуществлении } \\
\text { антикоррупционного просвещения }\end{array}$ & & \\
\hline 1.2. & $\begin{array}{l}\text { Наличие нормативного правового акта по размещению информации по вопросам } \\
\text { противодействия коррупции на официальном сайте органа публичной власти }\end{array}$ & & \\
\hline 1.3. & $\begin{array}{l}\text { Наличие раздела об организации и осуществлении антикоррупционного просвеще- } \\
\text { ния в программе (плане) по противодействию коррупции }\end{array}$ & & \\
\hline \multirow[t]{2}{*}{1.4.} & $\begin{array}{l}\text { Наличие закрепления в региональном законодательстве антикоррупционного про- } \\
\text { свещения как средства противодействия коррупции }\end{array}$ & & \\
\hline & Раздел II. Оценка качества правового регулирования антикоррупционнс & ого просвещения & \\
\hline 2.1. & $\begin{array}{l}\text { Предусмотрено ли нормативными правовыми актами антикоррупционное инфор- } \\
\text { мирование }\end{array}$ & & \\
\hline 2.2 . & $\begin{array}{l}\text { Предусмотрено ли нормативными правовыми актами антикоррупционное консуль- } \\
\text { тирование }\end{array}$ & & \\
\hline
\end{tabular}




\section{Государственная и муниципальная служба и проблемы противодействия коррупции}

\begin{tabular}{|c|c|c|c|}
\hline 1 & 2 & \multicolumn{2}{|l|}{3} \\
\hline 2.3. & $\begin{array}{l}\text { Имеется ли в нормативных правовых актах перечень субъектов антикоррупционно- } \\
\text { го просвещения }\end{array}$ & & \\
\hline 2.4. & $\begin{array}{l}\text { Предусмотрены ли в нормативных правовых актах средства на осуществление анти- } \\
\text { коррупционного просвещения }\end{array}$ & & \\
\hline 2.5. & $\begin{array}{l}\text { Имеются ли в нормативных правовых актах показатели оценки качества антикор- } \\
\text { рупционного просвещения }\end{array}$ & & \\
\hline 2.6. & $\begin{array}{l}\text { Предусмотрен ли нормативными правовыми актами контроль за осуществлением } \\
\text { антикоррупционного просвещения }\end{array}$ & & \\
\hline & Раздел III. Оценка качества организации осуществления антикоррупционI & Іого просв & ещения \\
\hline & Показатель & да & нет \\
\hline 3.1. & $\begin{array}{l}\text { Наличие специализированного органа и/или лица, уполномоченного на организа- } \\
\text { цию осуществление антикоррупционного просвещения }\end{array}$ & & \\
\hline 3.2. & Наличие средств, условий и возможностей антикоррупционного просвещения & & \\
\hline 3.3. & Организовано мероприятий по вопросам антикоррупционного просвещения & & \\
\hline 3.3.1. & Организовано «горячих линий» по вопросам антикоррупционного просвещения & & \\
\hline 3.3.2. & Организовано коллегий по вопросам организации антикоррупционного просвещения & & \\
\hline 3.3.3. & Организовано совещаний по вопросам организации антикоррупционного просвещения & & \\
\hline 3.3.4. & Организовано конференций по вопросам противодействия коррупции & & \\
\hline 3.3.5. & Организовано круглых столов по вопросам противодействия коррупции & & \\
\hline 3.3.6. & $\begin{array}{l}\text { Организовано научно-практических семинаров по вопросам противодействия кор- } \\
\text { рупции }\end{array}$ & & \\
\hline 3.4 . & $\begin{array}{l}\text { Наличие органа или лица, уполномоченного на антикоррупционное консультирова- } \\
\text { ние государственных (муниципальных) служащих и/или иных лиц }\end{array}$ & & \\
\hline 3.5. & $\begin{array}{l}\text { Наличие системы организации антикоррупционного образования для лиц, органи- } \\
\text { зующих и/или осуществляющих антикоррупционное просвещение }\end{array}$ & & \\
\hline 3.6. & $\begin{array}{l}\text { Наличие государственного (муниципального) контроля за осуществлением анти- } \\
\text { коррупционного просвещения }\end{array}$ & & \\
\hline 3.7. & $\begin{array}{l}\text { Периодичность государственного (муниципального) контроля за осуществлением } \\
\text { антикоррупционного просвещения }\end{array}$ & & \\
\hline 3.7.1. & Ежеквартально & & \\
\hline 3.7.2. & Каждое полугодие & & \\
\hline 3.7.3. & Ежегодно & & \\
\hline 3.8. & $\begin{array}{l}\text { Периодичность организации и осуществления мониторинга осуществления анти- } \\
\text { коррупционного просвещения }\end{array}$ & & \\
\hline 3.8.1. & Ежеквартально & & \\
\hline 3.8.2. & Каждое полугодие & & \\
\hline 3.8.3. & Ежегодно & & \\
\hline 3.9. & $\begin{array}{l}\text { Наличие механизмов и инструментов общественного контроля за организацией и } \\
\text { осуществлением антикоррупционного просвещения }\end{array}$ & & \\
\hline 3.10. & Наличие стендов с информацией по вопросам противодействия коррупции & & \\
\hline & Раздел IV. Оценка качества исполнения антикоррупционного просвещени & я его субъ & ектами \\
\hline & Показатель & & Количество \\
\hline 1 & 2 & & 3 \\
\hline 4.1. & $\begin{array}{l}\text { Проведено коллегий по вопросам организации и осуществления антикоррупционно } \\
\text { щения }\end{array}$ & просве- & \\
\hline 4.2. & $\begin{array}{l}\text { Проведено совещаний по вопросам организации и осуществления антикоррупциоң } \\
\text { свещения }\end{array}$ & ного про- & \\
\hline 4.3. & Проведено конференций по вопросам противодействия коррупции & & \\
\hline 4.3.1. & Приняло участие в конференции (человек) & & \\
\hline 4.3.2. & Научно-педагогических кадров & & \\
\hline 4.3.3. & Государственных служащих & & \\
\hline 4.3.4. & Муниципальных служащих & & \\
\hline 4.3 .5 & Иных лиц & & \\
\hline 4.4. & Проведено круглых столов по вопросам противодействия коррупции & & \\
\hline 4.4.1. & Приняло участие в мероприятии (человек) & & \\
\hline 4.4.2. & Научно-педагогических кадров & & \\
\hline 4.4.3. & Государственных служащих & & \\
\hline 4.4.4. & Муниципальных служащих & & \\
\hline 4.4.5. & Иных лиц & & \\
\hline 4.5. & Проведено научно-практических семинаров по вопросам противодействия корруг & & \\
\hline 4.5.1. & Приняло участие в мероприятии (человек) & & \\
\hline & & & \\
\hline
\end{tabular}


Административное и муниципальное право 8 (92) • 2015

\begin{tabular}{|c|c|c|}
\hline 1 & 2 & 3 \\
\hline 4.5.3. & Государственных служащих & \\
\hline 4.5 .4 . & Муниципальных служащих & \\
\hline 4.5 .5 . & Иных лиц & \\
\hline 4.6. & $\begin{array}{l}\text { Представлено и опубликовано в СМИ информационных материалов по вопросам антикорруп- } \\
\text { ционного просвещения }\end{array}$ & \\
\hline 4.7. & Выпущенных в эфир программ по вопросам антикоррупционного просвещения & \\
\hline 4.8. & Проведено «прямых линий» по вопросам антикоррупционного просвещения & \\
\hline 4.9. & Лица, получившие антикоррупционное консультирование & \\
\hline 4.9 .1 . & Государственные служащие & \\
\hline 4.9 .2 . & Муниципальные служащие & \\
\hline 4.9 .3 . & Лица, замещающие государственные должности РФ & \\
\hline 4.9.4. & Лица, замещающие государственные должности субъекта РФ & \\
\hline 4.9.5. & Лица, замещающие муниципальные должности & \\
\hline 4.9.6. & Руководители хозяйствующих субъектов & \\
\hline 4.9 .7 . & Иные категории лиц & \\
\hline 4.10 . & Подготовлено памяток по вопросам противодействия коррупции & \\
\hline 4.10.1. & Опубликовано памяток по вопросам противодействия коррупции (экз.) & \\
\hline 4.10.2. & Распространено памяток по вопросам противодействия коррупции (экз.) & \\
\hline 4.11. & Подготовлено методических пособий по вопросам противодействия коррупции & \\
\hline 4.11.1. & Опубликовано методических пособий по вопросам противодействия коррупции (экз.) & \\
\hline 4.11.2. & Распространено методических пособий по вопросам противодействия коррупции (экз.) & \\
\hline 4.12. & Лица, осуществляющие антикоррупционное просвещение & \\
\hline 4.12.1. & Государственные служащие & \\
\hline 4.12.2. & Муниципальные служащие & \\
\hline 4.12.3. & $\begin{array}{l}\text { Представители институтов гражданского общества, вовлеченные в антикоррупционную дея- } \\
\text { тельность (члены антикоррупционных советов (комиссий), общественных палат (советов)) }\end{array}$ & \\
\hline 4.12.4. & Научно-педагогические кадры & \\
\hline 4.13. & $\begin{array}{l}\text { Лица, прошедшие повышение квалификации по вопросам организации и осуществления анти- } \\
\text { коррупционного просвещения }\end{array}$ & \\
\hline 4.14. & Наличие стендов с материалами, направленными на антикоррупционное просвещение & \\
\hline 4.15. & $\begin{array}{l}\text { Наличие положительных отзывов в средствах массовой коммуникации по вопросам организа- } \\
\text { ции и осуществления антикоррупционного просвещения }\end{array}$ & \\
\hline
\end{tabular}

\section{Библиография:}

1. Воронцов С.А. Об организации антикоррупционного просвещения в Российской Федерации // Северо-Кавказский юридический вестник. - 2015. - №1. - С.105-111.

2. Гармаев Ю.П., Фалилеев В.А. Реализация мер антикоррупционного просвещения органами прокуратуры во взаимодействии с юридическими вузами // Государственная власть и местное самоуправление. - 2015. - №1. - С.1115.

3. Землин А.И. О новациях и деформациях антикоррупционного просвещения и воспитания в современной России // Противодействие терроризму. Проблемы XXI века. - COUNTER-TERRORISM. - 2014. - №2. - C.47-53.

4. Кабанов П.А. Антикоррупционное просвещение как средство противодействия коррупции: понятие и содержание // Актуальные проблемы экономики и права. - 2014. - №4. - С.42-51.

5. Кабанов П.А. О формировании Программы мероприятий, направленных на повышение уровня правосознания граждан и популяризацию антикоррупционных стандартов поведения, основанных на знании общих прав и обязанностей // Следователь. - 2014. - №1. - С.27-29.

6. Кабанов П.А. Понятие и содержание антикоррупционного просвещения как средства профилактики коррупции // Юридические исследования. - 2015. - № 2. - С.12-27.

7. Корякин В.М. Антикоррупция - 2014: приоритет - борьбе с «откатами» и антикоррупционное просвещение военнослужащих // Право в Вооруженных силах. - 2014. - №12 (210). - С.8-13.

8. О Государственной программе Кабардино-Балкарской Республики "Профилактика правонарушений и укрепление общественного порядка и общественной безопасности в Кабардино-Балкарской Республике" на 2013-2020 годы: постановление Правительства КБР от 2 сентября 2013 года №240-ПП (ред. от 26.12.2014 №306-ПП)// Официальная Кабардино-Балкария. - 2013. - 6 сентяб.

9. О департаменте региональной безопасности Костромской области: постановление Губернатора Костромской области от 14 мая 2009 года №104 (в ред. от 8.02.2012 №41) // Северная правда. - 2009. - 21 мая.

10. О мерах по противодействию коррупции в Ярославской области: закон Ярославской области от 9 июля 2009 года №40-3 // Губернские ведомости. - 2009. - 13 июля.

11. О министерстве юстиции Новосибирской области: постановление Губернатора Новосибирской области от 13июля 2012 года №120 (в ред. от 28.08.2014 №131) // Советская Сибирь. - 2012. - 31 июля. 
12. о мониторинге деятельности структурных подразделений (соответствующих должностных лиц) органов государственной власти Ямало-Ненецкого автономного округа, иных государственных органов Ямало-Ненецкого автономного округа по профилактике коррупционных и иных правонарушений: постановление Губернатора Ямало-Ненецкого автономного округа от 26 июня 2012 года №88-ПГ (ред. от 23.04.2013 №46-ПГ) // Красный Север. - 2012. - 6 июля.

13. О мониторинге деятельности структурных подразделений (соответствующих должностных лиц) органов местного самоуправления муниципальных образований в Ямало-Ненецком автономном округе по профилактике коррупционных и иных правонарушений: постановление Губернатора Ямало-Ненецкого автономного округа от 14 октября 2013 года №157-ПГ //Красный Север. - 2013. - 22 октяб.

14. О некоторых вопросах организации деятельности исполнительных органов государственной власти Пензенской области по противодействию коррупции: распоряжение Губернатора Пензенской области от 8 апреля 2014 года №100-р (ред. от 03.02.2015 №22-р).

15. О Перечне мероприятий по реализации антикоррупционного законодательства в Республике Дагестан на 20152016 годы: Распоряжение Главы Республики Дагестан от 5 февраля 2015 года №7-рг.

16. П Порядке проведения антикоррупционного мониторинга: распоряжение Главы Удмуртской Республики от 19 марта 2014 года №20-РГ.

17. О Порядке проведения мониторинга коррупции и мер реализации антикоррупционной политики (антикоррупционного мониторинга) в Республике Хакасия: приказ Аппарата Правительства Республики Хакасия от 26 сентября 2014 года №81.

18. О представлении информации о ходе реализации мер по противодействию коррупции структурными подразделениями центрального аппарата ФАС России и территориальными органами ФАС России: приказ Федеральной антимонопольной службы РФ от 27 сентября 2010 года №550.

19. О проведении ежеквартального мониторинга выполнения антикоррупционных мероприятий: Письмо Роспотребнадзора от 23 сентября 2010 года №01/12189-0-32.

20. О Программе противодействия коррупции в Удмуртской Республике на 2014-2015 годы: указ Президента Удмуртской Республики от 6 февраля 2014 года №12.

21. О противодействии коррупции в Астраханской области: закон Астраханской области от 26 ноября 2008 года №626-31-03 // Волна. - 2008. - 9 декаб.

22. О противодействии коррупции в Белгородской области: закон Белгородской области от 7 мая 2010 года №338 // Белгородские известия. - 2010. - 28 мая.

23. О противодействии коррупции в городе Севастополе: закон города Севастополя от 11 июня 2014 года №30-3С // Севастопольские известия. - 2014. - 18 июня.

24. О противодействии коррупции в Красноярском крае: закон Красноярского края от 7 июля 2009 года №8-3610 // Ведомости высших органов государственной власти Красноярского края. - 2009. - №37 (333).

25. О противодействии коррупции в органах государственной власти Псковской области и органах местного самоуправления: закон Псковской области от 1 июля 2008 года №784-03 // Псковская правда. - 2008. - 24 июля.

26. О противодействии коррупции в Республике Башкортостан: закон Республики Башкортостан от 13 июня 2009 года №143-3 // Ведомости Государственного Совета - Курултая, Президента и Правительства Республики Башкортостан. - 2009. - №17 (311). - Ст.1078.

27. О противодействии коррупции в Ульяновской области: закон Ульяновской области 20 июля 2012 года №89-30 (ред. от 02.12.2014 №204-30) // Ульяновская правда. - 2012. - 24 июля.

28. скорректированном плане по антикоррупционному просвещению на 2010-2011 годы: приказ Управления по делам печати, издательства и полиграфии при Правительстве Республики Башкортостан от 31 мая 2010 года №172/1-ОД;

29. Об организации проведения "прямых линий" с гражданами по вопросам антикоррупционного просвещения, отнесенным к сфере деятельности комитета образования и науки Волгоградской области: приказ министерства образования и науки Волгоградской области от 24 декабря 2014 года №1690 (ред. от 17.02.2015 №171) // Волгоградская правда. - 2015. - 21 янв.

30. Об отчетности по реализации федерального законодательства и законодательства Ямало-Ненецкого автономного округа по вопросам государственной гражданской службы: постановление Губернатора Ямало-Ненецкого автономного округа от 24 ноября 2011 года №194-ПГ (ред. от 1.04.2015 №46-ПГ) // Красный Север. - 2011. - 29 нояб.

31. Об утверждении государственной программы "Совершенствование государственного управления": постановление Правительства Пермского края от 3 октября 2013 года №1327-п (ред. от 24.04.2015 №255-п) // Бюллетень законов Пермского края, правовых актов губернатора Пермского края, Правительства Пермского края, исполнительных органов государственной власти Пермского края. - 2013. - 14 октяб.

32. Об утверждении областной программы «Противодействие коррупции в Ульяновской области» на 2013-2015 годы: постановление Правительства Ульяновской области от 1 января 2013 года №12/106-П.

33. Об утверждении областной целевой программы «Противодействие коррупции в Ярославской области» на 2014-2015 годы: постановление Правительства Ярославской области от 27 января 2014 года №56-п (в ред. от 12.03.2015 №256-п) // Документы Регион. - 2014. - 4 февр. 
34. Об утверждении Плана мероприятий по антикоррупционному просвещению в Республике Крым на 20152016 годы: распоряжение Совета министров Республики Крым от 26 декабря 2014 №1584-р.

35. Об утверждении положения об организации и порядке проведения "прямой линии" с гражданами по вопросам антикоррупционного просвещения, отнесенным к сфере деятельности администрации Изобильненского муниципального района Ставропольского края: Постановление администрации Изобильненского муниципального района Ставропольского края от 13 марта 2015 года №485 // Изобильненский муниципальный вестник. 2015. - 25 марта.

36. Об утверждении положения о министерстве образования и науки Архангельской области: постановление Правительства Архангельской области от 27 марта 2014 года №120-пп (в ред. от 3.06.2014 №229-пп) // Волна. 2014. - 10 апр.

37. Об утверждении Положения об Управлении по вопросам реализации антикоррупционной политики КарачаевоЧеркесской Республики: указ Президента Карачаево-Черкесской Республики от 19 ноября 2010 года №237 // День Республики. - 2010. - 30 нояб.

38. Об утверждении Порядка осуществления антикоррупционного мониторинга исполнительными органами государственной власти Иркутской области: постановление Правительства Иркутской области от 25 ноября 2013 г. №531-пп (ред. от 31.03.2015 №107-пп) // Областная. - 2014. - 15 янв..

39. Об утверждении Порядка проведения антикоррупционного мониторинга: Постановление Правительства Новосибирской области от 20 октября 2011 №458-п (ред. от 24.02.2014 №79-п) // Советская Сибирь. - 2011. - 8 нояб.

40. Об утверждении программы «Антикоррупционное просвещение в Новосибирской области на 2015-2016 годы»: постановление Правительства Новосибирской области от 28 января 2015 года № 26-п // Советская Сибирь. 2015. - 21 февр.

41. Об утверждении Программы мероприятий по противодействию коррупции в Пермском крае на 2012-2013 годы: указ Губернатора Пермского края от 23 марта 2012 года №19.

42. Об утверждении Программы по антикоррупционному просвещению в Республике Дагестан на 2014-2016 годы: распоряжение Правительства Республики Дагестан от 21 августа 2014 года №263-р.

43. Об утверждении Программы по антикоррупционному просвещению на 2014-2016 годы: распоряжение Правительства РФ от 14 мая 2014 года №816-р // Собрание законодательства РФ. - 2014. - №21. - Ст. 2721.

44. Об утверждении Программы противодействия коррупции в Иркутской области на 2014-2016 годы: распоряжение Правительства Иркутской области от 30 мая 2014 года №428-рп (в ред. от 30.03.2015 №164-рп) // Областная. - 2014. - 27 июня.

45. Общими силами - к подъему России (о положении в стране и основных направлениях политики Российской Федерации): послание Президента Российской Федерации Федеральному Собранию от 17 февраля 1998 года // Российская газета. - 1998. - 24 февр.

46. Отчет о реализации областной долгосрочной целевой программы «Противодействие коррупции в Ростовской области» на 2010-2014 годы за 2011 год: постановление Правительства Ростовской области от 17 мая 2012 года №398.

47. Ураев Р.Р. Актуальные аспекты антикоррупционного просвещения населения (на примере Республики Башкортостан) // Научное обеспечение инновационного развития АПК: материалы Всероссийской научно-практической конференции. - М., 2010. - С.322-323.

48. Хайрутдинова Л.Р. Антикоррупционное просвещение как эффективный способ противодействия коррупции // Диалектика противодействия коррупции: материалы IV Всероссийской научно-практической конференции, 3 декабря 2014 г. - Казань, 2014. - С.188-191.

49. Хайрутдинова Л.Р. Антикоррупционное просвещение: понятие, цели и значение // Гуманитарные научные исследования. - 2015. - №1-1 (41). - С.106-109.

50. Юсупов М.Р. Антикоррупционное просвещение в России - апологет правовой грамотности // Вертикальная власть федерации. - 2015. - №2-3. - С.5.

\section{References (transliterated):}

1. Vorontsov S.A. Ob organizatsii antikorruptsionnogo prosveshcheniya v Rossiiskoi Federatsii // Severo-Kavkazskii yuridicheskii vestnik. - 2015. - №1. - S.105-111.

2. Garmaev Yu.P., Falileev V.A. Realizatsiya mer antikorruptsionnogo prosveshcheniya organami prokuratury vo vzaimodeistvii s yuridicheskimi vuzami // Gosudarstvennaya vlast' i mestnoe samoupravlenie. - 2015. - №1. - S.11-15.

3. Zemlin A.I. O novatsiyakh i deformatsiyakh antikorruptsionnogo prosveshcheniya i vospitaniya v sovremennoi Rossii // Protivodeistvie terrorizmu. Problemy XXI veka. - COUNTER-TERRORISM. - 2014. - №2. - S.47-53.

4. Kabanov P.A. Antikorruptsionnoe prosveshchenie kak sredstvo protivodeistviya korruptsii: ponyatie i soderzhanie // Aktual'nye problemy ekonomiki i prava. - 2014. - №4. - S.42-51.

5. Kabanov P.A. O formirovanii Programmy meropriyatii, napravlennykh na povyshenie urovnya pravosoznaniya grazhdan i populyarizatsiyu antikorruptsionnykh standartov povedeniya, osnovannykh na znanii obshchikh prav i obyazannostei // Sledovatel'. - 2014. - №1. - S.27-29. 
6. Kabanov P.A. Ponyatie i soderzhanie antikorruptsionnogo prosveshcheniya kak sredstva profilaktiki korruptsii // Yuridicheskie issledovaniya. - 2015. - № 2. - S.12-27.

7. Koryakin V.M. Antikorruptsiya - 2014: prioritet - bor'be s «otkatami» i antikorruptsionnoe prosveshchenie voennosluzhashchikh // Pravo v Vooruzhennykh silakh. - 2014. - №12 (210). - S.8-13.

8. O Gosudarstvennoi programme Kabardino-Balkarskoi Respubliki "Profilaktika pravonarushenii i ukreplenie obshchestvennogo poryadka i obshchestvennoi bezopasnosti v Kabardino-Balkarskoi Respublike" na 2013-2020 gody: postanovlenie Pravitel'stva KBR ot 2 sentyabrya 2013 goda №240-PP (red. ot 26.12.2014 №306-PP)// Ofitsial'naya KabardinoBalkariya. - 2013. - 6 sentyab.

9. O departamente regional'noi bezopasnosti Kostromskoi oblasti: postanovlenie Gubernatora Kostromskoi oblasti ot 14 maya 2009 goda №104 (v red. ot 8.02.2012 №41) // Severnaya pravda. - 2009. - 21 maya.

10. O merakh po protivodeistviyu korruptsii v Yaroslavskoi oblasti: zakon Yaroslavskoi oblasti ot 9 iyulya 2009 goda №40-Z // Gubernskie vedomosti. - 2009. - 13 iyulya.

11. O ministerstve yustitsii Novosibirskoi oblasti: postanovlenie Gubernatora Novosibirskoi oblasti ot 13 iyulya 2012 goda №120 (v red. ot 28.08.2014 №131) // Sovetskaya Sibir'. - 2012. - 31 iyulya.

12. O monitoringe deyatel'nosti strukturnykh podrazdelenii (sootvetstvuyushchikh dolzhnostnykh lits) organov gosudarstvennoi vlasti Yamalo-Nenetskogo avtonomnogo okruga, inykh gosudarstvennykh organov Yamalo-Nenetskogo avtonomnogo okruga po profilaktike korruptsionnykh i inykh pravonarushenii: postanovlenie Gubernatora YamaloNenetskogo avtonomnogo okruga ot 26 iyunya 2012 goda №88-PG (red. ot 23.04.2013 №46-PG) // Krasnyi Sever. 2012. - 6 iyulya.

13. O monitoringe deyatel'nosti strukturnykh podrazdelenii (sootvetstvuyushchikh dolzhnostnykh lits) organov mestnogo samoupravleniya munitsipal'nykh obrazovanii v Yamalo-Nenetskom avtonomnom okruge po profilaktike korruptsionnykh i inykh pravonarushenii: postanovlenie Gubernatora Yamalo-Nenetskogo avtonomnogo okruga ot 14 oktyabrya 2013 goda №157-PG //Krasnyi Sever. - 2013. - 22 oktyab.

14. O nekotorykh voprosakh organizatsii deyatel'nosti ispolnitel'nykh organov gosudarstvennoi vlasti Penzenskoi oblasti po protivodeistviyu korruptsii: rasporyazhenie Gubernatora Penzenskoi oblasti ot 8 aprelya 2014 goda №100-r (red. ot 03.02.2015 №22-r).

15. O Perechne meropriyatii po realizatsii antikorruptsionnogo zakonodatel'stva v Respublike Dagestan na 2015-2016 gody: Rasporyazhenie Glavy Respubliki Dagestan ot 5 fevralya 2015 goda №7-rg.

16. O Poryadke provedeniya antikorruptsionnogo monitoringa: rasporyazhenie Glavy Udmurtskoi Respubliki ot 19 marta 2014 goda №20-RG.

17. O Poryadke provedeniya monitoringa korruptsii i mer realizatsii antikorruptsionnoi politiki (antikorruptsionnogo monitoringa) v Respublike Khakasiya: prikaz Apparata Pravitel'stva Respubliki Khakasiya ot 26 sentyabrya 2014 goda №81.

18. O predstavlenii informatsii o khode realizatsii mer po protivodeistviyu korruptsii strukturnymi podrazdeleniyami tsentral'nogo apparata FAS Rossii i territorial'nymi organami FAS Rossii: prikaz Federal'noi antimonopol'noi sluzhby RF ot 27 sentyabrya 2010 goda №550.

19. O provedenii ezhekvartal'nogo monitoringa vypolneniya antikorruptsionnykh meropriyatii: Pis'mo Rospotrebnadzora ot 23 sentyabrya 2010 goda №01/12189-0-32.

20. O Programme protivodeistviya korruptsii v Udmurtskoi Respublike na 2014-2015 gody: ukaz Prezidenta Udmurtskoi Respubliki ot 6 fevralya 2014 goda №12.

21. O protivodeistvii korruptsii v Astrakhanskoi oblasti: zakon Astrakhanskoi oblasti ot 26 noyabrya 2008 goda №626-31-0Z // Volna. - 2008. - 9 dekab.

22. O protivodeistvii korruptsii v Belgorodskoi oblasti: zakon Belgorodskoi oblasti ot 7 maya 2010 goda №338 // Belgorodskie izvestiya. - 2010. - 28 maya.

23. O protivodeistvii korruptsii v gorode Sevastopole: zakon goroda Sevastopolya ot 11 iyunya 2014 goda №30-ZS // Sevastopol'skie izvestiya. - 2014. - 18 iyunya.

24. O protivodeistvii korruptsii v Krasnoyarskom krae: zakon Krasnoyarskogo kraya ot 7 iyulya 2009 goda №8-3610 // Vedomosti vysshikh organov gosudarstvennoi vlasti Krasnoyarskogo kraya. - 2009. - №37 (333).

25. O protivodeistvii korruptsii v organakh gosudarstvennoi vlasti Pskovskoi oblasti i organakh mestnogo samoupravleniya: zakon Pskovskoi oblasti ot 1 iyulya 2008 goda №784-OZ // Pskovskaya pravda. - 2008. - 24 iyulya.

26. Oprotivodeistviikorruptsiiv Respublike Bashkortostan: zakon Respubliki Bashkortostan ot13 iyunya2009 goda №143-Z// Vedomosti Gosudarstvennogo Soveta - Kurultaya, Prezidenta i Pravitel'stva Respubliki Bashkortostan. - 2009. - №17 (311). - St.1078.

27. O protivodeistvii korruptsii v Ul'yanovskoi oblasti: zakon Ul'yanovskoi oblasti 20 iyulya 2012 goda №89-ZO (red. ot 02.12.2014 №204-ZO) // Ul'yanovskaya pravda. - 2012. - 24 iyulya.

28. O skorrektirovannom plane po antikorruptsionnomu prosveshcheniyu na 2010-2011 gody: prikaz Upravleniya po delam pechati, izdatel'stva i poligrafii pri Pravitel'stve Respubliki Bashkortostan ot 31 maya 2010 goda №172/1-OD;

29. Ob organizatsii provedeniya "pryamykh linii" s grazhdanami po voprosam antikorruptsionnogo prosveshcheniya, otnesennym k sfere deyatel'nosti komiteta obrazovaniya i nauki Volgogradskoi oblasti: prikaz ministerstva obrazovaniya i nauki Volgogradskoi oblasti ot 24 dekabrya 2014 goda №1690 (red. ot 17.02.2015 №171) // Volgogradskaya pravda. 2015. - 21 yanv. 
30. Ob otchetnosti po realizatsii federal'nogo zakonodatel'stva i zakonodatel'stva Yamalo-Nenetskogo avtonomnogo okruga po voprosam gosudarstvennoi grazhdanskoi sluzhby: postanovlenie Gubernatora Yamalo-Nenetskogo avtonomnogo okruga ot 24 noyabrya 2011 goda №194-PG (red. ot 1.04.2015 №46-PG) // Krasnyi Sever. - 2011. - 29 noyab.

31. Ob utverzhdenii gosudarstvennoi programmy "Sovershenstvovanie gosudarstvennogo upravleniya": postanovlenie Pravitel'stva Permskogo kraya ot 3 oktyabrya 2013 goda №1327-p (red. ot 24.04.2015 №255-p) // Byulleten' zakonov Permskogo kraya, pravovykh aktov gubernatora Permskogo kraya, Pravitel'stva Permskogo kraya, ispolnitel'nykh organov gosudarstvennoi vlasti Permskogo kraya. - 2013. - 14 oktyab.

32. Ob utverzhdenii oblastnoi programmy «Protivodeistvie korruptsii v Ul'yanovskoi oblasti» na 2013-2015 gody: postanovlenie Pravitel'stva Ul'yanovskoi oblasti ot 1 yanvarya 2013 goda №12/106-P.

33. Ob utverzhdenii oblastnoi tselevoi programmy «Protivodeistvie korruptsii v Yaroslavskoi oblasti» na 2014-2015 gody: postanovlenie Pravitel'stva Yaroslavskoi oblasti ot 27 yanvarya 2014 goda №56-p (v red. ot 12.03.2015 №256-p) // Dokumenty Region. - 2014. - 4 fevr.

34. Ob utverzhdenii Plana meropriyatii po antikorruptsionnomu prosveshcheniyu v Respublike Krym na 2015-2016 gody: rasporyazhenie Soveta ministrov Respubliki Krym ot 26 dekabrya 2014 №1584-r.

35. Ob utverzhdenii polozheniya ob organizatsii i poryadke provedeniya "pryamoi linii" s grazhdanami po voprosam antikorruptsionnogo prosveshcheniya, otnesennym k sfere deyatel'nosti administratsii Izobil'nenskogo munitsipal'nogo raiona Stavropol'skogo kraya: Postanovlenie administratsii Izobil'nenskogo munitsipal'nogo raiona Stavropol'skogo kraya ot 13 marta 2015 goda №485 // Izobil'nenskii munitsipal'nyi vestnik. - 2015. - 25 marta.

36. Ob utverzhdenii polozheniya o ministerstve obrazovaniya i nauki Arkhangel'skoi oblasti: postanovlenie Pravitel'stva Arkhangel'skoi oblasti ot 27 marta 2014 goda №120-pp (v red. ot 3.06.2014 №229-pp) // Volna. - 2014. - 10 apr.

37. Ob utverzhdenii Polozheniya ob Upravlenii po voprosam realizatsii antikorruptsionnoi politiki Karachaevo-Cherkesskoi Respubliki: ukaz Prezidenta Karachaevo-Cherkesskoi Respubliki ot 19 noyabrya 2010 goda №237 // Den' Respubliki. 2010. - 30 noyab.

38. Ob utverzhdenii Poryadka osushchestvleniya antikorruptsionnogo monitoringa ispolnitel'nymi organami gosudarstvennoi vlasti Irkutskoi oblasti: postanovlenie Pravitel'stva Irkutskoi oblasti ot 25 noyabrya 2013 g. №531-pp (red. ot 31.03.2015 №107-pp) // Oblastnaya. - 2014. - 15 yanv..

39. Ob utverzhdenii Poryadka provedeniya antikorruptsionnogo monitoringa: Postanovlenie Pravitel'stva Novosibirskoi oblasti ot 20 oktyabrya 2011 №458-p (red. ot 24.02.2014 №79-p) // Sovetskaya Sibir'. - 2011. - 8 noyab.

40. Ob utverzhdenii programmy «Antikorruptsionnoe prosveshchenie v Novosibirskoi oblasti na 2015-2016 gody»: postanovlenie Pravitel'stva Novosibirskoi oblasti ot 28 yanvarya 2015 goda № 26-p // Sovetskaya Sibir'. - 2015. - 21 fevr.

41. Ob utverzhdenii Programmy meropriyatii po protivodeistviyu korruptsii v Permskom krae na 2012-2013 gody: ukaz Gubernatora Permskogo kraya ot 23 marta 2012 goda №19.

42. Ob utverzhdenii Programmy po antikorruptsionnomu prosveshcheniyu v Respublike Dagestan na 2014-2016 gody: rasporyazhenie Pravitel'stva Respubliki Dagestan ot 21 avgusta 2014 goda №263-r.

43. Ob utverzhdenii Programmy po antikorruptsionnomu prosveshcheniyu na 2014-2016 gody: rasporyazhenie Pravitel'stva RF ot 14 maya 2014 goda №816-r // Sobranie zakonodatel'stva RF. - 2014. - №21. - St. 2721.

44. Ob utverzhdenii Programmy protivodeistviya korruptsii v Irkutskoi oblasti na 2014-2016 gody: rasporyazhenie Pravitel'stva Irkutskoi oblasti ot 30 maya 2014 goda №428-rp (v red. ot 30.03.2015 №164-rp) // Oblastnaya. - 2014. 27 iyunya.

45. Obshchimi silami - k pod"emu Rossii (o polozhenii v strane i osnovnykh napravleniyakh politiki Rossiiskoi Federatsii): poslanie Prezidenta Rossiiskoi Federatsii Federal'nomu Sobraniyu ot 17 fevralya 1998 goda // Rossiiskaya gazeta. - 1998. - 24 fevr.

46. Otchet o realizatsii oblastnoi dolgosrochnoi tselevoi programmy «Protivodeistvie korruptsii v Rostovskoi oblasti» na 2010-2014 gody za 2011 god: postanovlenie Pravitel'stva Rostovskoi oblasti ot 17 maya 2012 goda №398.

47. Uraev R.R. Aktual'nye aspekty antikorruptsionnogo prosveshcheniya naseleniya (na primere Respubliki Bashkortostan) // Nauchnoe obespechenie innovatsionnogo razvitiya APK: materialy Vserossiiskoi nauchno-prakticheskoi konferentsii. - M., 2010. - S.322-323.

48. Khairutdinova L.R. Antikorruptsionnoe prosveshchenie kak effektivnyi sposob protivodeistviya korruptsii // Dialektika protivodeistviya korruptsii: materialy IV Vserossiiskoi nauchno-prakticheskoi konferentsii, 3 dekabrya 2014 g. - Kazan', 2014. - S.188-191.

49. Khairutdinova L.R. Antikorruptsionnoe prosveshchenie: ponyatie, tseli i znachenie // Gumanitarnye nauchnye issledovaniya. - 2015. - №1-1 (41). - S.106-109.

50. Yusupov M.R. Antikorruptsionnoe prosveshchenie v Rossii - apologet pravovoi gramotnosti // Vertikal'naya vlast' federatsii. - 2015. - №2-3. - S.5. 